\title{
The genera Ascobolus and Saccobolus (Ascobolaceae, Pezizales) in Brazil
}

\author{
Melo RFR ${ }^{1}$, Miller AN ${ }^{3}$, Santiago ALCMA ${ }^{2}$ and Maia LC ${ }^{1}$ \\ ${ }^{1}$ Universidade Federal de Pernambuco, Departamento de Micologia, Centro de Ciências Biológicas, Avenida da \\ Engenharia, s/n, 50740-600, Recife, Pernambuco, Brazil.rogerfrmelo@gmail.com \\ ${ }^{2}$ Illinois Natural History Survey, University of Illinois, 1816 S. Oak St., Champaign, IL 61820 \\ ${ }^{3}$ Universidade Federal Rural de Pernambuco, Unidade Acadêmica de Serra Talhada, Fazenda Saco, sn., caixa postal \\ 063, Serra Talhada, Pernambuco, Brazil
}

Melo RFR, Miller AN, Santiago ALCMA, Maia LC 2014 - The genera Ascobolus and Saccobolus (Ascobolaceae, Pezizales) in Brazil. Mycosphere 5(6), 790-804, Doi 10.5943/mycosphere/5/6/9

\begin{abstract}
Coprophilous species of Ascobolus and Saccobolus from Brazil are poorly known. Fourteen species were identified from fresh herbivore dung recently collected in Pernambuco, Northeastern Brazil, and eight exsiccatti sets were revised from the Pe. Camille Torrend (URM) and Dárdano de Andrade Lima (IPA) herbaria. Ascobolus elegans and S. beckii are reported for the first time in South America, while Ascobolus americanus and Saccobolus saccoboloides are reported for the first time in Brazil. Saccobolus infestans is neotypified. Information regarding the distribution and substrate preference of these species is presented. Descriptions and plates are provided, along with an identification key to all known species of Ascobolus and Saccobolus in Brazil.
\end{abstract}

Key words - Ascomycota - dung fungi - taxonomy

\section{Introduction}

Ascobolaceae comprises six genera and approximately 129 species, composed mainly of saprobic species associated with herbivore dung (Kirk et al. 2008). The group contain species with small, fleshy apothecia, usually with a furfuraceous or villose disk due to the protruding asci bearing dark coloured ascospores in maturity, asci clavate to saccate, with dome-shaped or truncated apices, opening by a conspicuous operculum, and ascospores free or united in a single cluster, usually dark, in shades of red, purple or brown, with a smooth to strongly ornamented episporium (Van Brummelen 1967). Representatives of Ascobolaceae are predominantly coprophilous, but some species have been recorded in vegetable material and burnt substrates (Richardson 2007).

Most species of Ascobolaceae belong to Ascobolus and Saccobolus, both genera occurring worldwide and commonly found throughout the year (Richardson 2001b). Within the pigmented spored genus that have flesh and excipula (formerly allocated in Ascoboloideae tribe), the former contain free ascospores inside the asci, while the later have ascospores strongly cemented together in clusters, even after their liberation.

In Brazil, the knowledge of these genera is still scarce. In compiling the fungi studied by Batista and colleagues, da Silva \& Minter (1995) mentioned only two typical coprophilous ascomycetes, being Ascobolus notatus Batista \& A.F. Vital one of them. During a visit to Brazil in 
1998, Richardson (2001a) sampled herbivore dung and recorded A. immersus Pers., Saccobolus citrinus Boud. \& Torrend, S. depauperatus (Berk. \& Broome) E.C. Hansen, S. truncatus Velen., S. verrucisporus Brumm. and S. versicolor (P. Karst.) P. Karst. in Bonito and Pantanal of Rio Negro, Mato Grosso do Sul, providing a brief description for these six species.

In the present work, Ascobolus and Saccobolus recorded in Brazil are discussed, along with the recent new additions from fresh material collected in Pernambuco, Northeastern Brazil, herbaria and bibliographic revision, and aspects regarding substrate preference and distribution.

\section{Materials \& Methods}

\section{Study area and sampling}

Dung samples were collected from: 1) animal precincts on the campus of Universidade

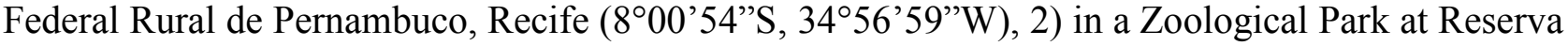
Ecológica de Dois Irmãos, Recife $\left(8^{\circ} 7^{\prime} 30^{\prime}\right.$ 'S, 34 $\left.52^{\prime} 30^{\prime \prime} \mathrm{W}\right), 3$ ) on farms close to the Instituto Agronônico de Pernambuco (IPA) in Caruaru ( $\left.8^{\circ} 01^{\prime} 59^{\prime \prime} \mathrm{S}, 36^{\circ} 06^{\prime} 59^{\prime \prime} \mathrm{W}\right)$ and in Serra Talhada (7'54'59'S, 38 $\left.8^{\circ} 17^{\prime} 0.14^{\prime \prime} \mathrm{W}\right)$, both located on Caatinga domain in the semi-arid region of Pernambuco. Samples of cattle (Bos sp.), goat (Capra sp.) and horse (Equus sp.) dung were collected in all areas, while samples of camel (Camelus bactrianus L.), llama (Lama glama L.), deer (Cervus elaphus L), paca (Cuniculus paca L.) and waterbuck (Kobus ellipsiprymnus L.) dung were available on the Zoo park at Dois Irmãos. Samples were collected in clean plastic bags, gently air dried when necessary, taken to the laboratory and incubated in moist chambers at room temperature $\left(28 \pm 2{ }^{\circ} \mathrm{C}\right)$ for at least 60 days under alternating natural light and dark periods. The specimen habit was observed directly from substrata under a stereomicroscope (Leica EZ4), and apothecia in different stages of development were mounted in tap water, lactophenol with cotton blue or Polyvinyl-Lacto-Glycerol (PVLG) for observation under light microscopy. Species were identified based on morphology in different stages of development according to Van Brummelen (1967), Bell (1983), Richardson \& Watling (1997), Doveri (2004), Bell (2005) and Doveri (2014). Shannon's diversity index was used as an estimator of species diversity in each substratum and in the assemblage as a whole (Shannon 1948). A careful literature revision and a survey of national herbaria were performed in order to access information regarding older records of the studied genera in Brazil. Exsiccatti were requested in herbaria Pe. Camille Torrend (URM), Dárdano de Andrade Lima (IPA), both in Pernambuco, Maria Eneyda P. Kaufmann Fidalgo (IBT), São Paulo, Instituto Nacional de Pesquisas da Amazônia (INPA), Amazonas, Museu Paraense Emilio Goeldi (MG), Minas Gerais, Instituto de Biociências, Universidade Federal do Rio Grande do Sul (INC), Rio Grande do Sul, and Dimitri Sucre Benjamin (JBRJ), Rio de Janeiro, where all exsiccates containing material of Ascobolus and Saccobolus collected in Brazil were searched and, if located, taxonomically revised, with similar methodology. High resolution images of morphological characters were taken with the aid of a BX51 Olympus microscope equipped with bright-field and Nomarski interference optics. Permanent slides were mounted and deposited in URM (Pe. Camille Torrend Herbarium, Universidade Federal de Pernambuco, Recife, Brazil).

\section{Results}

Fourteen species were identified from fresh material, showing apothecia fruiting directly on dung, and another eight species from exsiccati containing relevant dry material from herbaria were examined. An identification key to the coprophilous species of Ascobolus and Saccobolus in Brazil is provided.

\section{Key to species of Ascobolus and Saccobolus from Brazil}

1. Ascospores free inside the asci in all stages of development

1. Ascospores firmly cemented together in all or some stage of development ............................... 6 
2. Apothecia eugymnohymenial, large, usually visible with naked eye, up to $1500 \mu \mathrm{m}$ diam. Disk strongly furfuraceous

A. scatigenus

2. Apothecia cleistohymenial, smaller, up to $600 \mu \mathrm{m}$ diam. Disk punctate to weakly furfuraceous .. 3

3. Apothecia opening on the telohymenial phase. Episporium with a pattern of subparallel crevices, occasionally anastomosing

3. Apothecia opening on the mesohymenial phase. Episporium smooth or finely granular, sometimes with a few fissures....

4. Receptacle with a prominent, crenulate margin. Episporium with a regular pattern of longitudinal fissures. Ascospores 10-15 × 6.5-7.5 $\mu \mathrm{m}$

A. crenulatus

4. Receptacle with an acute, finely denticulate margin. Episporium with a regular pattern of fine, closely spaced fissures. Ascospores $22-27.5 \times 12-13.5 \mu \mathrm{m}$.

A. levisporus

5. Ascospores more than $50 \mu \mathrm{m}$ long, surrounded by a gelatinous sheath.....

A.immersus

5. Ascospores smaller. Gelatinous sheath present or absent

6. Ascospores 32.5-37.5 × 15.5-17 $\mu \mathrm{m}$

A.americanus

6. Ascospores $27.5-32 \times 12.5-15 \mu \mathrm{m}$ A.elegans

7. Spore-clusters loose, visible in young asci only. Ascospores free at maturity ....... S. saccoboloides

7. Spore-clusters compact even after liberation. Spores firmly cemented even after liberation........ 8

8. Spore-clusters with four rows of two longitudinally disposed spores and two longitudinal planes of symmetry

8. Spore-clusters with a different pattern of spore arrangement

9. Receptacle yellow to lemon-yellow. Ascospores with strongly truncate ends

S. citrinus

9. Receptacle golden-yellow to amber. Ascospores without strongly truncate ends

10. Receptacle strongly colored, in shades of ember. Ascospores $25-27.5 \times 7.5-12.5 \mu \mathrm{m} . . . S$. glaber 10. Receptacle weakly colored, in shades of yellow. Ascospores smaller, less than $20 \mu \mathrm{m}$ long.... 11

11. Ascospores $13-20 \times 8-9.5 \mu \mathrm{m}$. Spore-clusters becoming shorter at maturity S. truncatus 11. Ascospores $11.5-12.5 \times 5-7.5 \mu \mathrm{m}$. Spore-clusters not shortening at maturity S. minimus

12. Spore-clusters with the axes of the spores at right angles to the axis of the package, with four pairs united in a cylindrical cluster S. infestans

12. Spore-clusters with a different pattern of spore arrangement 13

13. Spore-clusters with two rows of three and one row of two spores, where the axis of spores are parallel to the axis of the cluster

S. verrucisporus 13. Spore-cluster with two rows of three and one row of two spores, where the two terminal pair of spores are parallel to the axis of the cluster and the two median pairs are obliquely disposed........ 14

14. Episporium thick, coarsely warted or reticulated. Ascospores 17.5-22.5 ×8.5-10 $\mu \mathrm{m} \ldots$... beckii 14. Episporium smooth to finely granular, sometimes with an incomplete network of fissures...... 15

15. Spore-clusters $29-32 \times 9.5-12 \mu \mathrm{m}$. Ascospores $11.5 \times 6-6.5 \mu \mathrm{m}$ S. depauperatus 15. Spore-clusters 38-48 × 16-20 $\mu \mathrm{m}$. Ascospores 14.5-19 × 7-10 $\mu \mathrm{m}$ S. versicolor

\section{Taxonomy}


Ascobolus americanus (Cooke \& Ellis) Seaver, North American Cup-fungi (Operculates) 85.1928.

Figs $1-3$

$\equiv$ Ascobolus leveillei var. americanus Cooke \& Ellis, Florule Finistère (Paris) 35. 1876.

= Ascobolus amoenus Oudem., Hedwigia 21(11). 1882.

Apothecia gregarious to scattered, sessile, semi-immersed or superficial, 250-600 × 150-500 $\mu \mathrm{m}$, glabrous. Receptacle globose and closed at first, dark-yellow, becoming subglobose, yellow, with undifferentiated margin. Disk red to dark-purple due to many exposed protruding thin asci bearing mature ascospores. Hymenium well developed, 245-310 $\mu \mathrm{m}$ thick. Hypothecium thin, composed of small oblong cells. Excipulum composed of subglobose and angular cells, (textura angularis and textura globulosa), with well differentiated layers. Paraphyses filiform, simple or branched, sometimes septate, hyaline, 2-3 $\mu \mathrm{m}$ thick, embedded in greenish-yellow substance in some apothecia, easily observed when mounting in water. Asci 8-spored, clavate to cylindricclavate, with a short stalk, rounded above, 215-295 × 30-44.5 $\mu \mathrm{m}$. Ascospores uniseriate, becoming biseriate with maturation, ellipsoid, hyaline when young, becoming violet to brownishred in maturity, smooth to finely granular, 32.5-37.5 $\times 15.5-17 \mu \mathrm{m}$.

Habitat - Recorded on dung of blue wildebeest, camel, cattle, elephant, giraffe, goat, horse, rabbit and muskrat.

Known distribution - Africa (South Africa), Europe (Netherlands), North America (U.S.A., Canada) and South America (Argentina, Peru, Venezuela). This is the first record from Brazil.

Material examined - Brazil, Pernambuco, Serra Talhada, Instituto Agronômico de Pernambuco (IPA), on cattle dung, 30 May 2012, R.F.R. Melo (URM84600, 84601); on goat dung, 10 Jun 2011, R.F.R. Melo (URM84603); on horse dung: 23 Apr 2012, R.F.R. Melo (URM84602); 8 Sep 2011, R.F.R. Melo (URM84599).

Notes - This species is similar to A. elegans, and can be distinguished mainly by the size of the ascospores $(32.5-37.5 \times 15.5-17 \mu \mathrm{m})$ and by a somewhat furfuraceous disk, with several simultaneously protruding asci.

Ascobolus crenulatus P. Karst., Fungi Fenniae Exsiccati, 8(763), 1868.

Figs 4-6 = Ascobolus viridulus W. Phillips \& Plowr., Grevillea 8(47): 103, 1880.

Apothecia isolated, sessile, superficial, $0.5-0.6 \mathrm{~mm}$ diam., glabrous. Receptacle at first globose, with undifferentiated disk, pale yellow to yellow, then hemispheric to lenticular, greenishyellow, and finally darker, in shades of dark yellow to amber colored with the ripening of ascospores, with crenulated margin. Disk with violaceous to purplish punctuation due to the coloured episporium of ascospores inside the protruding asci at maturity, weakly furfuraceous. Hymenium well differentiated, 120-200 $\mu \mathrm{m}$ thick. Hypothecia poorly differentiated, composed of small globose cells and hyphae, usually indistinct from the hymenium. Excipulum composed of globose and subglobose cells (textura globosa), with poorly differentiated layers. Paraphyses cylindric, simple or branched, septate, hyaline, 2.5-3 $\mu \mathrm{m}$ thick. Asci 8-spored, cylindric-clavate, shortening towards the base to form a short stalk, rounded above, 135-145.5 $\times 12.5-15 \mu \mathrm{m}$. Ascospores uniseriate when maturing, finally becoming irregularly biseriate, ellipsoid, hyaline when young, becoming violaceous to pale red, with episporium presenting parallel fissures, longitudinal to the spore main axis, occasionally anastomosing, 10-15 $\times 6.5-7.5 \mu \mathrm{m}$, sometimes with unilateral mucilagenous substance.

Habitat - Recorded in vegetable material and in dung of deer, dog, goat, grouse, partridge, pheasant, pigeon, porcupine, raven and rabbit.

Known distribution - Worldwide.

Material examined - Brazil, Pernambuco, Recife, Universidade Federal Rural de Pernambuco (UFRPE), on goat dung, 23 Sep 2011, R.F.R. Melo (URM85922, 85923).

Notes - As suggested by the etymology of its specific epithet (lat. crenulatus = notched, serrated), this species has, as a main distinguishing morphological character, receptacles with crenulated margin. It represents a typical member of Van Brummelen's Ascobolus Section, with 
episporium presenting a pattern of subparallel fissures, longitudinal with the spore main axis, occasionally anastomosing. Despite being well distributed, it was recorded in Brazil only once, in Pernambuco, fruiting on goat dung.

Ascobolus elegans J. Klein, Verh. zool.-bot. Ges. Wien 20: 566. 1870.

Figs $7-8$

$\equiv$ Ascophanus elegans (J. Klein) Sacc., Syll. fung. (Abellini) 10: 32. 1892.

$\equiv$ Dasyobolus elegans (J. Klein) Svrcek. Sb. nár. Mus. Praze 32B(2-4): 117. 1979.

Apothecia gregarious to scattered, sessile, usually superficial, 300-400 $\mu \mathrm{m}$ diam., glabrous. Receptacle globose at first, greenish yellow, becoming subglobose andyellow at maturity, with undifferentiated margin. Disk poorly distinct, with red to purple dots due to exposed protruding asci bearing mature ascospores. Hymenium well developed, 200-250 $\mu \mathrm{m}$ thick. Hypothecium thin, composed of small globular to subglobular cells. Excipulum composed of angular and subglobose cells, becoming elongated next to the surface, (textura angularis, textura epidermoidea or textura globulosa), with poorly differentiated layers. Paraphyses filiform, simple or branched, septate, hyaline, 2.5-3 $\mu \mathrm{m}$ thick, embedded in greenish-yellow substance in some apothecia, easily observed when mounted in water. Asci 8-spored, clavate, tapering towards the base to form a short stipe, rounded above, 210-257.5 × 31-35.5 $\mu \mathrm{m}$. Ascospores biseriate, ellipsoid, hyaline when young, becoming violet to brownish-red in maturity, smooth to finely granular, 27.5-32 × 12.5-15 $\mu \mathrm{m}$.

Habitat - Recorded on dung of cattle, giraffe, goose, hare, horse, rabbit and zebra.

Known distribution - Europe (Denmark, Germany, Great Britain, Poland, Sweden) and North America (U.S.A.). This is the first record from South America.

Material examined - Brazil, Pernambuco, Caruaru, Instituto Agronômico de Pernambuco (IPA), on horse dung, 15 Jun 2011, R.F.R. Melo (URM84604, 84605).

Notes - Ascobolus elegans can be distinguished from other representatives of section Dasyobolus by ascospore dimensions, smaller than A. americanus (Cooke \& Ellis) Seaver and larger than A. mancus (Rehm) Brumm., and by epispore ornamentation, smooth to finely granular (Van Brummelen 1967).

Ascobolus immersus Pers., Neues Mag. Bot. 1: 115. 1794.

Figs 9-11

$\equiv$ Dasyobolus immersus (Pers.) Sacc., Syll. fung. (Abellini) 11:421. 1895.

Apothecia usually scattered, sessile, 500-1200 $\mu \mathrm{m}$ diam., glabrous. Receptacle globose to ovoid and closed at first, dark-yellow to greenish-brown, immersed to erumpent, becoming subglobose to pyriform, yellow, superficial, without margin. Disk with $\sim 3-7$ exposed protruding asci and its ascospores, easily observed in stereomicroscope. Hymenium composed of few exposed asci. Hypothecium thin, composed of small isodiametric cells, poorly observable. Excipulum composed of angular, subglobose or oblong cells, (textura angularis and textura globosa), with layers poorly differentiated after maturation. Paraphyses filiform, simpleor branched, septate, hyaline, $2-3 \mu \mathrm{m}$ thick, in greenish-yellow substance in some apothecia, easily observed when mounted in water. Asci 8-spored, broadly clavate, with a short stalk, rounded above, 394-445 $\times$ 107-130 $\mu \mathrm{m}$, greatly elongated before spore liberation, reaching $\sim 690-700 \mu \mathrm{m}$. Ascospores biseriateor irregularly disposed in the asci, variable in morphology, oblong to ellipsoid, sometimes subglobose, hyaline when young, becoming purple or violet, finally in shades of red to purplishbrown, smooth or with one to few fissure lines, 57.5-62.5 $\times 30-35 \mu \mathrm{m}$, surrounded by a thick gelatinous envelope.

Habitat - Recorded on dung of many herbivores.

Known distribution - Worldwide.

Material examined - Brazil, Pernambuco, Caruaru, Instituto Agronômico de Pernambuco (IPA), on cattle dung, 17 Jun 2011, R.F.R. Melo (URM84606); Serra Talhada, Instituto Agronômico de Pernambuco (IPA), on horse dung, 15 Jun 2011, R.F.R. Melo (URM84609); Recife, Universidade Federal Rural de Pernambuco (UFRPE), on horse dung, 12 Sep 2011, R.F.R. Melo (URM84607); 12 Mar 2012, R.F.R. Melo (URM84608); Recife, on guinea pig dung, 1 Dec 
1947, Batista A.C. (URM653, IPA37905, IPA1129); Recife, Dois Irmãos, on rabbit dung, 1 Dec 1947, Pontual D. (URM646, IPA37903).

Notes - Ascobolus immersus is one of the most common fungi found fruiting on incubated herbivore dung, being recorded worldwide. It can be easily recognized by its very large ascospores $(57.5-62.5 \times 30-35 \mu \mathrm{m})$ surrounded by a conspicuous gelatinous envelope. In Brazil, this species was recorded by Richardson (2001a), Batista et al. (1961), among other authors. No apothecia was found on material reviewed under the labels URM653 and IPA37905, but well preserved apothecia were found on material in the box number 1129 in IPA herbarium, along with the holotype of Chaetomium brasiliense Bat \& Pontual. Ascobolus cuniculorum A.C. Batista \& Pontual was proposed for specimens found on rabbit dung identified by Chaves Batista in Pernambuco, Brazil, but was later synonymized under A. immersus Pers. by Van Brummelen (1967). No apothecia were found on both exsiccati, available from two different herbaria. The holotype of A. cuniculorum consisted of a single dry pellet of rabbit dung with several pseudothecia of Sporormiella minima (Auersw.) S.I. Ahmed \& Cain, but no apothecia could be found. Thus, based on the revision of the aforementioned author, "Ascobolus cuniculorum A.C. Batista \& Pontual" was nomenclaturally superfluous when published, and should stand as a synonym of Ascobolus immersus Pers.

Ascobolus scatigenus (Berk. \& M.A. Curtis) Brumm., Persoonia, Suppl. 1: 159. 1967. Figs 12-14 $\equiv$ Sphaeria scatigena Berk. \& Broome, Annals and Magazine of Natural History 7: 452. 1861.

三 Hypocopra scatigena (Berk. \& Broome) Sacc., Sylloge Fungorum 1: 243. 1882.

$\equiv$ Coniochaeta scatigena (Berk. \& Broome) Cain, Studies of Coprophilous Spaeriales in Ontario: 62. 1934.

$\equiv$ Ascobolus notatus A.C. Batista \& A.F. Vital, Anais Soc. Biol. Pernambuco 13(2): 61. 1955. =Ascobolus magnificus B.O. Dodge, Mycologia 4(4): 218. 1912.

Apothecia scattered to gregarious, sessile, superficial, $1.5-2.7 \mathrm{~mm}$, glabrous. Receptacle initially subglobular, white to pale luteous, exposing the disk during the beginning of development, with undifferentiated hymenium, bearing immature asci, later becoming lageniform, cupulate and finally scutellate, pale yellow, granular in texture, with involute, poorly differentiated margin. Disk plane to slightly undulate, strongly furfuraceous, dark-red to black coloured due to many exposed protruding thin asci bearing mature ascospores. Hymenium well differentiated, 190-215 $\mu \mathrm{m}$ thick. Hypothecium composed of small, hyaline, globose cells, 5-10 $\mu \mathrm{m}$ thick. Excipulum composed of small globose and subglobose cells (textura globulosa), hyaline, 50-75 $\mu \mathrm{m}$ thick.Paraphyses abundant, cylindric, simples or occasionally branched, septate, hyaline, 2.5-3.5 $\mu \mathrm{m}$ diam., slightly larger towards the apex, up to $6.5 \mu \mathrm{m}$ diam., occasionally longer than the asci in the hymenium. Asci 8-spored, cylindric-clavate, with a short stalk, rounded to slightly tapered above, with prominent opercula, 175-225 × 17.5-30 $\mu \mathrm{m}$. Ascospores uniseriate, ellipsoid, hyaline when young, then violaceous to brownish-red, smooth or with one to a few oblique fissure, usually inconspicuous, $22-24.5 \times 10-15 \mu \mathrm{m}$.

Habitat - Recorded on dung of many herbivores.

Known distribution - Worldwide.

Material examined - Brazil, Pernambuco, Serra Talhada, Instituto Agronômico de Pernambuco (IPA), on cattle dung, 16 Feb 2012, R.F.R Melo (URM85924); Recife, Universidade Federal Rural de Pernambuco (UFRPE), on cattle dung, 19 Nov 2012, R.F.R Melo (URM85925); Recife, on cattle dung, 1 Dec 1947, Vital A.F. (URM1976).

Notes - Ascobolus scatigenus has relatively large receptacles, usually visible on the substrate with the unaided eye, on dung surface under incubation, or in situ. The eugymnohymenial ascomata, furfuraceous disk, composed of protruding asci with ellipsoid ascospores $(22-24.5 \times 10$ $15 \mu \mathrm{m}$ ), usually with a single to a few oblique fissures on its episporium, distinguishes this species. It resembles $A$. castaneus, which differs by having different apothecium ontogeny, ascospores smaller and smooth episporium. The exsiccate URM1976, labeled with the denomination Ascobolus notatus A.C. Batista \& A.F. Vital contains sessile apothecia, previously revised by van Brummelen (1976) as A. scatigenus (Berk.) Brumm., comb. nov. in his monograph. The material 
contains apothecia scattered, sessile, superficial, 900-1200 $\mu \mathrm{m}$ diam.; receptacle cup-shaped, with somewhat involute margin; disk concave; hymenium $\sim 200 \mu \mathrm{m}$ thick; excipulum not clearly observable due to the state of preservation of the apothecia; asci cylindric-clavate, 150-195.5 $\times$ 17.5-23.5 $\mu \mathrm{m}$; ascospores ellipsoid, 20-27.5 × 12.5-15 $\mu \mathrm{m}$. The identification of A. scatigenus sensu van Brummelen was confirmed. The name $A$.notatus A.C. Batista \& A.F. Vital stands as a synonym of $A$. scatigenus (Berk.) Brumm., comb. nov.

Saccobolus beckii Heimerl, Österr. Ascob.: 18. 1889.

Figs 15-16

Apothecia gregarious or scattered, sessile, superficial, 400-650 $\mu \mathrm{m}$ diam, glabrous. Receptacle globular at first, becoming pulvinate, light yellow, with undifferentiated margin. Disk convex, dotted with black protruding tips of asci bearing ripe ascospore clusters. Hymenium 8.5$12.2 \mu \mathrm{m}$. Hypothecium undifferentiated. Excipulum thin, composed of interwoven hyphae. Paraphyses cylindric, simple, septate, hyaline, 2-3 $\mu \mathrm{m}$ thick. Asci 8-spored, clavate, tapering towards the base, with a truncate apex and a short stipe, 150-165 $\times 41-45.5 \mu \mathrm{m}$. Spore clusters arranged in a pattern with two rows of three and one row of two spores, 50-55 $\times 18-22 \mu \mathrm{m}$, at the apical portion inside the asci, surrounded by a thin gelatinous sheath. Ascospores ellipsoid, hyaline when young, becoming dark-brown to black in maturity, with thick episporium composed of coarse warts, 17.5-22.5 × 8.5-10 $\mu \mathrm{m}$.

Habitat - Recorded from dung of cattle, deer, elephant and zebra. New additions on horse and goat dung arepresented.

Known distribution - Africa (South Africa) and Europe (Austria, Bermuda, France, Germany, Great Britain). This is the first record from South America.

Material examined - Brazil, Pernambuco, Caruaru, Instituto Agronômico de Pernambuco (IPA), on goat dung, 3 Jan 2012, R.F.R. Melo (URM84612); Recife, Universidade Federal Rural de Pernambuco (UFRPE), on goat dung, 7 Aug 2012, R.F.R. Melo (URM84610, 84611).

Notes - Saccobolus beckii can be easily distinguished by the ornamentation pattern of the spore cluster and by its coarsely warted episporium (Van Brummelen, 1967, Bell, 1983).

Saccobolus citrinus Boud. \& Torrend, Bull. Soc. mycol. Fr. 27(2): 131. 1911.

Figs $17-19$

Apothecia gregarious to scattered, sessile, superficial, 300-400 $\mu \mathrm{m}$ diam., glabrous. Receptacle scuttelate, discoid, pulvinate or lenticular, light yellow to yellow when young, becoming dark yellow to ochraceous with age, with undifferentiated margin. Disk convex, dotted with black protruding tips of asci bearing ripe ascospore clusters. Hymenium poorly developed. Hypothecium undifferentiated. Excipulum thin,composed of a palisade of cells inundifferentiated layers. Paraphyses cylindric, simple, septate, hyaline, 2-3 $\mu \mathrm{m}$ thick, slightly enlarged at apex, embedded in greenish-yellow substance in some apothecia, easily observed when mountedin water. Asci 8-spored, clavate, tapering towards the base, with a truncate apex and a short stipe, 110-150 $\times$ 30-33 $\mu \mathrm{m}$. Spore clusters arranged in a pattern with four columns, each containing two spores, 47.5-55 $\times 15-20 \mu \mathrm{m}$, at the apical portion inside the asci, surrounded by a thin gelatinous sheath. Ascospores biseriate, ellipsoid, hyaline when young, becoming brownish-red to purple in maturity, with an ornamentation of fine isolated warts, $20-23 \times 7.5-11 \mu \mathrm{m}$.

Habitat - Recorded on dung of many herbivores.

Known distribution - Worldwide.

Material examined - Brazil, Pernambuco, Serra Talhada, Instituto Agronômico de Pernambuco (IPA), on cattle dung, 10 Oct 2011, R.F.R Melo (URM84613); 26 Dec 2011, R.F.R Melo (URM84617); 1 Mar 2013, R.F.R Melo (URM84616); Recife, Universidade Federal Rural de Pernambuco (UFRPE), on cattle dung, 3 Apr 2012, R.F.R Melo (URM84618); on goat dung, 15 Jun 2012, R.F.R Melo (URM84614, 84615).

Notes - Saccobolus citrinus is one of the most common species of the genus with the $2 \times 4$ spore-cluster pattern, easily found in dung of herbivores in damp chambers. The species can be distinguished from $S$. glaber by the slightly smaller size of ascospores $(20-23 \times 8-10 \mu \mathrm{m})$, and the truncated ends of the ascospores, as well as the lemon-yellow color of the apothecia. 
Saccobolus depauperatus (Berk. \& Broome) Rehm, Vidensk. Meddel. Dansk Naturhist. Foren. Kjøbenhavn: 293. 1876.

Figs 20-21

$\equiv$ Ascobolus depauperatus Berk. \& Broome, Ann. Mag. nat. Hist., Ser. 3(15): 448. 1865.

Apothecia gregarious to scattered, sessile, superficial, up to $300 \mu \mathrm{m}$ diam., glabrous. Receptacle pulvinate, hyaline to pale violet, with undifferentiated margin. Disk convex, faintly violet, dotted with dark purplish protruding tips of asci bearing ripe ascospore clusters. Hymenium $62.5 \times 80 \mu \mathrm{m}$ thick. Hypothecium poorly observable in material examined. Excipulum composed of a very thin layer with globular and subglobular cells (textura globulosa). Paraphyses poorly observable in material examined. Asci 8 -spored, clavate, tapering towards the base, with a truncate apex and a short stipe, $70-95.5 \times 17.5-20 \mu \mathrm{m}$. Spore clusters arranged in a pattern with two rows of three and with one row of two spores, 32.5-36.5 × 10-15 $\mu \mathrm{m}$, sometimes asymmetrical. Ascospores fusoid to ellipsoid, hyaline when young, becoming purplish-brown at maturity, smooth or with an ornamentation of fine isolated warts, $11-15 \times 5-7.5 \mu \mathrm{m}$.

Habitat - Recorded from dung of cattle, chamois, deer, elephant, elk, hare, horse, porcupine, rabbit and sheep.

Known distribution - Africa (Morroco), Asia (Pakistan), Europe (Austria, Denmark, Faroe Islands, Finland, France, Germany, Great Britain, Iceland, Italy, Netherlands, Poland, Spain, Sweden), North America (Canada, U.S.A.), Oceania (Australia, New Zealand) and South America (Argentina, Brazil, Ecuador, Venezuela).

Material examined - Brazil, Pernambuco, Serra Talhada, Instituto Agronômico de Pernambuco (IPA), on cattle dung, 12 Sep 2011, R.F.R. Melo (URM84620); on goat dung, 16 May 2012, R.F.R. Melo (URM84619).

Notes - This is a common cosmopolitan species, rather variable in morphology, with small apothecia that can be distinguished from S. minimus Velen. by its spore-cluster arrangement and from S. versicolor (P. Karst.) P. Karst. by its smaller apothecia, asci and ascospores.

Saccobolus glaber (Pers.) Lambotte, Mém. Soc. roy. Sci. Liège, 14: 284. 1888.

Figs 24-25 $\equiv$ Ascobolus glaber Pers. Neues Mag. Bot. 1: 115. 1794.

Apothecia usually scattered, sometimes gregarious, sessile, superficial, 350-800 $\mu \mathrm{m}$ diam., glabrous. Receptacle globose to subglobose at first, becoming pulvinate, in shades of ambar, with undifferentiated margin. Disk convex, golden before asci ripening, later dotted with dark-purple to black protruding tips of asci bearing ripe ascospore clusters. Hymenium 162.5-200 $\mu \mathrm{m}$. Hypothecium undifferentiated. Excipulum thin, composed of small subglobose cells. Paraphyses cylindric, simple or branched near the apex, septate, hyaline, 3-3.5 $\mu \mathrm{m}$ thick, sometimes slightly enlarged at apex, with yellow contents in some apothecia, easily observed when mounted in water. Asci 8-spored, cylindric-clavate, 175.5-260 $\times 20-32 \mu \mathrm{m}$. Spore clusters arranged in a pattern with four columns, each containing two spores, 52.5-57.5 $\times 20-21.5 \mu \mathrm{m}$, at the apical portion inside the asci, surrounded by a thick gelatinous sheath, especially observable after spore cluster release. Ascospores ellipsoid to slightly fusiform, sometimes asymmetrical, hyaline when young, becoming purplish-brown in maturity, with rounded tips with an ornamentation of fine isolated warts, 25$27.5 \times 7.5-12.5 \mu \mathrm{m}$.

Habitat - Recorded from dung of bear, blue wildebeest, camel, cattle, deer, elephant, gnu, horse, sheep and zebu.

Known distribution - Worldwide.

Material examined - Brazil, Pernambuco, Caruaru, Instituto Agronômico de Pernambuco (IPA), on horse dung, 13 Jun 2012, R.F.R. Melo (URM84623); Serra Talhada, Instituto Agronômico de Pernambuco (IPA), on cattle dung, 26 Dec 2011, R.F.R. Melo (URM84621); Recife, Universidade Federal Rural de Pernambuco (UFRPE), on cattle dung, 3 Apr 2012, R.F.R. Melo (URM84622); 7 Aug 2012, R.F.R. Melo (URM84624); 3 Feb 2013, R.F.R. Melo (URM84625). 
Notes - Saccobolus glaber resembles S. citrinus Boud. \& Torrend in general morphology, being distinguished by the color of receptacle, usually darker, in shades of amber, golden to dark yellow, and for its slightly longer ascospores $(25-27.5 \mu \mathrm{m})$ with rounded tips.

Saccobolus infestans (Bat. \& Pontual) Brumm., Persoonia, Suppl. 1: 204. 1967.

Figs $22-23$ $\equiv$ Ascobolus infestans Bat. \& Pontual, Bol. Secr. Agric. (Pernambuco) 15: 31.1948.

Apothecia usually scattered, sometimes gregarious, sessile, superficial, 90-120 $\mu \mathrm{m}$ diam., glabrous. Receptacle globose to subglobose at first, becoming pulvinate, pale, with undifferentiated margin. Disk convex, white before asci ripening, later dotted with violaceous protruding tips of asci bearing ripe ascospore clusters. Hymenium $\sim 75 \mu \mathrm{m}$ thick. Hypothecium undifferentiated. Excipulum thin, composed of small angular cells. Paraphyses cylindric, simple or branched near the apex, septate, hyaline, 1-2.5 $\mu \mathrm{m}$ thick. Asci 8-spored, clavate, 75-110 × 14-20.5 $\mu \mathrm{m}$. Spore clusters arranged in a pattern with the axes of the spores at right angles to the axis of the cluster, 20-25.5 × 10-15 $\mu \mathrm{m}$. Ascospores ellipsoid, hyaline when young, becoming brown in maturity, with rounded tips, slightly roughened, 10-11 $\times 5-6 \mu \mathrm{m}$.

Habitat - Recorded from dung of donkey and horse.

Known distribution - Central America (Panama, Tahiti) and South America (Brazil, Venezuela).

Material examined - (neotypus) Brazil, Pernambuco, Recife, Universidade Federal Rural de Pernambuco (UFRPE), on horse dung, 6 Mar 2013, R.F.R. Melo (URM84632); (isoneotypus) Recife, Universidade Federal Rural de Pernambuco (UFRPE), on horse dung, 6 Mar 2013, R.F.R. Melo (URM84633).

Notes - Saccobolus infestans can be characterized by the unusual arrangement of its spore cluster. It resembles $S$. geminatus in having spores transversely arranged in the cluster, but differs in having smaller ascospores $(10-11 \times 5-6 \mu \mathrm{m})$ not firmly united in pairs. It was first described in Brazil by Batista \& Pontual (1948), from material collected on horse dung in Dois Irmãos, Recife, Pernambuco, as Ascobolus infestans Bat. \& Pontual. Despite the efforts, the exsiccate containing the holotype, deposited in IPA herbarium, could not be found. The original work where this name was proposed contained a short description and one picture, without drawings. Thus, according to the Article 9.7 of the International Code of Botanical Nomenclature (Melbourne Code), since there is material left from the holotype first designated, the recent material collected on the same substrate (horse dung) and locality (Dois Irmãos, Recife) is designated here as neotype (URM84632) and isoneotype (URM84633).

Saccobolus minimus Velen., Monogr. Discom. Bohem. (Prague) 1: 370. 1934.

Fig 26

Apothecia scattered, sessile, superficial, 100-175 $\mu \mathrm{m}$ diam., glabrous. Receptacle pulvinate, translucid light yellow to ochraceous, with undifferentiated margin. Disk convex, amber colored before ascospore ripening, dotted with black protruding tips of mature asci bearing ascospore clusters. Hymenium 45-65 $\mu \mathrm{m}$. Hypothecium undifferentiated. Excipulum thin, composed of globose cells on the lower part and by a palisade of cells on the upper part. Paraphyses cylindric to filiform, simple, septate, hyaline, 1.5-2.5 $\mu \mathrm{m}$ thick, with yellow contents, easily observed when mounting in water. Asci 8-spored, clavate, tapering towards the base, with a truncate apex and a short stipe, $50-55.5 \times 30-33 \mu \mathrm{m}$. Spore clusters compact, arranged in a pattern with four columns, each one containing two spores,27.5-30 $\times 10-15 \mu \mathrm{m}$, at the apical portion inside the asci, surrounded by a thin gelatinous sheath. Ascospores ellipsoid, hyaline when young, becoming pinkish-violet to purplish-brown in maturity, smooth to finely punctate, $11.5-12.5 \times 5-7.5 \mu \mathrm{m}$.

Habitat - Recorded from dung of camel, cow, deer, donkey, giraffe, goat, muskrat, sheepand zebra.

Known distribution - Africa (Kenya, South Africa), Asia (Thailand), North America (Canada, Hawaii, U.S.A.), Europe (Austria, Czech Republic, Germany, France, Italy, Poland, 
Spain), Oceania (New Zealand) and South America (Ecuador, Puerto Rico). This is the first record from Brazil.

Material examined - Brazil, Pernambuco, Serra Talhada, Instituto Agronômico de Pernambuco (IPA), on goat dung, 7 Oct 2012, R.F.R. Melo (URM84626).

Notes - According to Van Brummelen (1967), despite being a cosmopolitan species, $S$. minimus is rarely recorded due to its small size. It can be characterized by its ochraceous apothecia, pattern of spore-cluster arrangement and small ascospores $(11.5-12.5 \times 5-7.5 \mu \mathrm{m})$.

Saccobolus saccoboloides (Seaver) Brumm., Persoonia, Suppl. 1: 168. 1967.

Figs $27-30$ 三Ascobolus saccoboloides Seaver, Mycologia 38(6): 640. 1946.

Apothecia scattered, superficial, sessile, 300-900 $\mu \mathrm{m}$ in diam., glabrous. Receptacle lenticular, yellow when readily mature, becoming amber with age, then finally dark-brown to black. Disk dotted with a coppery staining due to the protruding tips of ripe asci. Hymenium well developed, $\sim 100 \mu \mathrm{m}$ thick. Hypothecium undifferentiated. Excipulum composed of globose cells, strongly cyanophilous. Paraphyses filiform, simple, septate, $2.5-3 \mu \mathrm{m}$ in diam.at the base, filled with yellowish contents (not observable in some mounting media). Asci 8-spored, clavate, with a short stalk and truncate apex, 70-87.5 $\times 16-22 \mu \mathrm{m}$, stretching up to $120 \mu \mathrm{m}$ long, with an easily observable operculum after spore release. Spore clusters cemented in a very early stage of development, assuming a pattern arrangement more or less regular, becoming free inside the ascibefore liberation. Ascospores irregularly arranged after separation, ellipsoid to somewhat fusoid, sometimes asymmetric, at first hyaline, becoming reddish brown when ripe, 12.5-16.5 $\times 5$ $7.5 \mu \mathrm{m}$, with smooth episporium.

Habitat - Recorded from pig dung. New additions to camel, deer, llama and waterbuck dung are presented.

Known distribution - Indonesia and New Guinea. This is the first record from Brazil.

Material examined - Brazil, Pernambuco, Recife, Horto Zoobotânico do Parque Estadual Dois Irmãos, on deer dung, 11 Sep 2009, R.F.R. Melo (URM82289); 25 Nov 2009, R.F.R. Melo (URM82293); on llama dung: 02 Oct 2009, R.F.R. Melo (URM82290); 07 May 2010, R.F.R. Melo (URM82298); on camel dung: 05 Oct 2009 R.F.R. Melo (URM82291); 10 Dec 2009, R.F.R. Melo (URM82294); 02 Feb 2010, R.F.R. Melo (URM82295); 05 Apr 2010, R.F.R. Melo (URM82297); on waterbuck dung, 20 Nov 2009, R.F.R. Melo (URM82292); 10 Mar 2010, R.F.R. Melo (URM82296).

Notes - Saccobolus saccoboloides represents an atypical member of the genus by the tendency of ascospores to separate inside the asci, and was placed by Dodge \& Seaver (1946) in Ascobolus as A. saccoboloides Seaver. However, other characters, such as the tendency of a loose spore cluster to form a somewhat regular pattern in young asci (four columns, each containing two spores), apothecium development and asci morphology, support the current placement of this species in Saccobolus.

Saccobolus truncatus Velen., Monogr. Discom. Bohem. (Prague): 370 (1934)

Figs 31-33

Apothecia scattered, sessile, superficial, 200-275 $\mu \mathrm{m}$ diam., glabrous. Receptacle semiglobular at first, becoming lenticular, light yellow, with undifferentiated margin. Disk convex, light yellow, dotted with dark brown to black protruding tips of asci bearing ripe ascospore clusters. Hymenium $\sim 45 \mu \mathrm{m}$ thick. Hypothecium not clearly observed in material examined. Excipulum thin, composed of globose cells on the lower part, and by a palisade of cells on the upper part. Paraphyses cylindric to clavate, simple or more rarely branched, septate, hyaline, $1.5-3.5 \mu \mathrm{m}$ thick, slightly enlarged at the apex. Asci 8-spored, clavate, tapering towards the base, with a truncate apex, $75-82.5 \times 17.5-20 \mu \mathrm{m}$. Spore clusters elongated to compact, arranged in a pattern with four columns, each containing two spores, 37.5-40 × 15.5-20 $\mu \mathrm{m}$, becoming shorter with spore maturation, to a point where the pattern of arrangement can not be distinguished, shortening to 27.5-30 $\mu \mathrm{m}$ long, surrounded by a thick gelatinous sheath. Ascospores ellipsoid, hyaline when 
young, becoming purple to purplish-brown in maturity, smooth to finely punctate, sometimes with fissures, 13-20 × 8-9.5 $\mu \mathrm{m}$.

Habitat - Recorded from dung of cow, horse, partridge, rabbit, raven and sheep. New addition to goat dung is presented.

Known distribution - Africa (Morroco), Asia (Thailand), Europe (Austria, Czech Republic, Denmark, France, Germany, netherlands), North America (Canada, U.S.A.) and South America (Brazil, Peru, Puerto Rico). This is the first record from northeastern Brazil.

Material examined - Brazil, Pernambuco, Serra Talhada, Instituto Agronômico de Pernambuco (IPA), on cattle dung, 6 Oct 2012, R.F.R.Melo (URM84630,84631); 14 Oct 2012, R.F.R.Melo (URM84627); Recife, Universidade Federal Rural de Pernambuco (UFRPE), on cattle dung, 3 Apr 2012, R.F.R.Melo (URM84628, 84629).

Notes - Saccobolus truncatus presents small pale yellow apothecia, usually scattered, resembling S. minimus Velen., but can be distinguished by the shape and size of ascospores, and by the tendency of the spore-cluster to become shortened in maturity.

Saccobolus versicolor (P. Karst.) P. Karst., Acta Soc. Fauna Flora fenn. 2(6): 123. $1885 . \quad$ Fig 34 $\equiv$ Ascobolus versicolor P. Karst., Bidr. Känn. Finl. Nat. Folk 19: 79. 1871.

Apothecia gregarious to scattered, superficial, up to $300 \mu \mathrm{m}$ diam., glabrous. Receptacle pulvinate to lenticular, lilaceous, with undifferentiated margin. Disk convex, light violet, dotted with purple protruding tips of asci bearing ripe ascospore clusters. Hymenium $\sim 120 \mu \mathrm{m}$ thick. Hypothecium not clearly observed in material examined. Excipulum thin, composed of intertwined hyphae and globose cells, barely observable in material examined. Paraphyses filiform, branched, septate, hyaline, 2-3 $\mu$ mthick, sometimes enlarged at the apex. Asci 8-spored, clavate, with a short stipe and truncated apex, tapering towards the base, $90-130 \times 25-33 \mu \mathrm{m}$. Spore Clustersarranged in a pattern with two rows of three and one row of two spores, 50-57 $\times 18.5-22.5 \mu \mathrm{m}$. Ascospores ellipsoid, violaceous to brown, smooth to finely roughened, 20-22.5 × 10-11.5 $\mu \mathrm{m}$.

Habitat - Recorded from dung of camel, caribou, cattle, deer, goat, hare, horse, lemming, mouse, muskrat, rabbit, reedbuck, sheep and steenbok. New addition to llama dung is presented.

Known distribution - Asia (China), Africa (Kenya), Europe (Austria, Belgium, Czech Republic, Denmark, Finland, France, Germany, Great Britain, Italy, Netherlands, Norway, Sweden, Switzerland, Poland, Romania, and Russia), North America (Canada, U.S.A), Oceania (New Zealand) and South America (Brazil, Chile).

Material examined - Brazil, Pernambuco, Recife, Horto Zoobotânico do Parque Estadual Dois Irmãos, on llama dung, 21 Aug 2009, R.F.R. Melo (URM82299).

Notes - Saccobolus versicolor shows great variability in its morphology. This species can be characterized by its spore-cluster arrangement, episporium smooth to finely granular and ascospore and spore cluster dimensions.

\section{Unverified and doubtful species}

\section{Ascobolus epixylon}

Name of unknown origin, not found in the literature. The species contained in this material at URM herbarium (URM7181) has pulvinate stromata, not related with any Ascobolus species. The exsiccate did not contained author names.

Ascobolus levisporus Speg., Anal. Mus. nac. Hist. nat. B. Aires 6: 307. 1898.

This species was only found in North and South America, and the type is in poor condition. It resembles A. furfuraceus, being distinguished by its larger apothecia and spaced striations in the episporium. It was first published by Spegazzini in Anales del Museo Nacional de Buenos Aires in 1899, recorded on cattle dung in La Plata, Argentina (Spegazinni, 1899), as "A. laevisporus Speg.". It occurs as a very rare species, being rarely described, apart from the known records. 


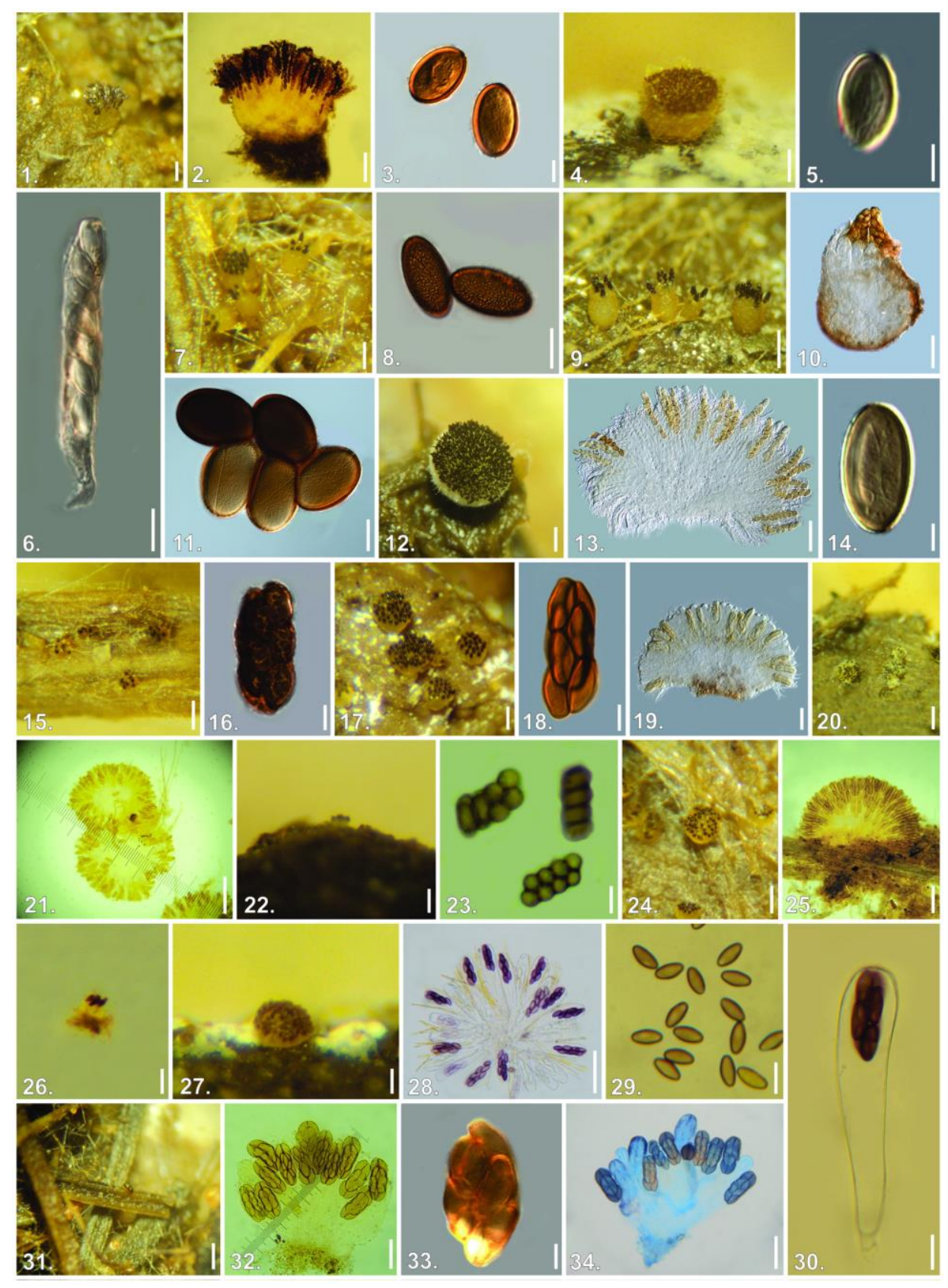

Figures 1-34 - Ascobolus americanus. (1) Apothecium on dung (Bar $=200 \mu \mathrm{m})$, (2) mounted apothecium $(\mathrm{Bar}=100 \mu \mathrm{m})$ and $(3)$ mature spores $(\mathrm{Bar}=10 \mu \mathrm{m})$. A. crenulatus. (4) Apothecium on dung $(\mathrm{Bar}=200$ $\mu \mathrm{m})$, (5) mature spores $(B a r=5 \mu \mathrm{m})$ and $(6)$ asci $(B a r=20 \mu \mathrm{m})$. A. elegans. $(7)$ Apothecium on dung $(B a r=$ $400 \mu \mathrm{m})$ and $(8)$ mature spores $(B a r=15 \mu \mathrm{m})$. A.immersus (9) Apothecium on dung $(B a r=750 \mu \mathrm{m}),(10)$ mounted apothecium $(\mathrm{Bar}=250 \mu \mathrm{m})$ and $(11)$ mature spores, with some visible fissures $(\mathrm{Bar}=25 \mu \mathrm{m})$. A. scatigenus. (12) Apothecium on dung $(\mathrm{Bar}=750 \mu \mathrm{m}),(13)$ mounted apothecium $(\mathrm{Bar}=250 \mu \mathrm{m})$ and $(14)$ mature spores $(\mathrm{Bar}=5 \mu \mathrm{m})$. Saccobolus beckii. $(15)$ Apothecium on dung $(\mathrm{Bar}=500 \mu \mathrm{m})$ and $(16)$ sporecluster, with cracked episporium $(\mathrm{Bar}=10 \mu \mathrm{m})$. S.citrinus. (17) Apothecium on dung $(\mathrm{Bar}=250 \mu \mathrm{m}),(18)$ spore cluster $(B a r=10 \mu \mathrm{m})$ and $(19)$ mounted apothecium $(\mathrm{Bar}=50 \mu \mathrm{m})$. S. depauperatus. (20) Apothecium on dung $(\mathrm{Bar}=250 \mu \mathrm{m})$ and $(21)$ mounted apothecium $(\mathrm{Bar}=100 \mu \mathrm{m})$. S. infestans. (22) Apothecium on dung $(\mathrm{Bar}=500 \mu \mathrm{m})$ and $(23)$ spore-clusters in different views $($ Bar $=20 \mu \mathrm{m})$. S. glaber. (24) Apothecium on dung $(\operatorname{Bar}=500 \mu \mathrm{m})$ and $(25)$ mounted apothecium $(\operatorname{Bar}=150 \mu \mathrm{m})$. S. minimus. $(26)$ Apothecium on dung $(\mathrm{Bar}=150 \mu \mathrm{m})$. S. saccoboloides. (27) Apothecium on dung $(\mathrm{Bar}=250 \mu \mathrm{m}),(28)$ mounted apothecium, with clearly observable paraphyses with yellowish contents $(B a r=50 \mu \mathrm{m})$, (29) free spores $(\mathrm{Bar}=15 \mu \mathrm{m})$ and $(30)$ asci with spores assuming the spore cluster arrangement, just before its disruption $(\mathrm{Bar}=10 \mu \mathrm{m})$. S. truncatus. (31) Apothecium on dung $(\mathrm{Bar}=500 \mu \mathrm{m})$, (32) mounted apothecium $(\mathrm{Bar}=50 \mu \mathrm{m})$ and $(33)$ shortened spore cluster $(\mathrm{Bar}=5 \mu \mathrm{m})$. S. versicolor. $(34)$ mounted apothecium $(\mathrm{Bar}=$ $50 \mu \mathrm{m})$. 


\section{Ascobolus sp.}

The exsiccate IPA37924, deposited in Dárdano de Andrade Lima herbarium in January $19^{\text {th }}$, 1948 contains a single dry pellet of frog dung, labeled "Ascobolus sp.". However, no apothecia were found at the time of the last revision or in this study, and the possibility of identification of this material remains lost with it.

Saccobolus verrucisporus Persoonia, Suppl. 1: 198. 1967.

Saccobolus verrucisporus var. longisporus S.C. Kaushal \& Virdi, Willdenowia 16(1): 274. 1986. During a survey of coprophilous fungi in Mato Grosso, Mid-west Brazil, Richardson (2001a) recorded $S$. verrucisporus for the first time in Brazil. The material consisted of "very small apothecia, 150-200 $\mu \mathrm{m}$ diam., with 10-12 simultaneously protruding exposed asci; asci $125 \times 29$ $\mu \mathrm{m}$; spore clusters $32-38 \times 16 \mu \mathrm{m}$; ascospores $12.5-16 \times 8-9.5 \mu \mathrm{m} "$. It was deposited in his personal collection under the code "MJR 62-63/98".

\section{Discussion}

From the recent survey carried out on dung fungi of domestic herbivores in Pernambuco (goat, horse and cattle), the most common species was Saccobolus citrinus, recorded on almost every sample brought to the laboratory, dominant on all three substrates studied (cattle, goat and horse dung) and areas surveyed (Caruaru, Recife and Serra Talhada), followed by Ascobolus immersus, fruiting soon upon incubation. Despite the lack of study at a national scale, these species are most likely widespread on domesticated herbivore dung throughout Pernambuco in a vegetational gradient that ranges from Atlantic Rainforests to semiarid Caatinga. Saccobolus saccoboloides, despite being rare, was the dominant species on samples collected at the Zoological Park in Dois Irmãos, Recife, by Melo et al. (2012). This species was recorded for the first time in Brazil, confirming the need for additional studies on these fungi. Saccobolus versicolor, despite being a common worldwide species, was poorly represented in the recent surveys, being recorded only once. Along with $S$. saccoboloides, A. americanus are reported for the first time in Brazil. Ascobolus elegans and S. beckii are reported for the first time in South America.

Regarding the substrate relationship, in general, species did not show a preference for specific dung types in most records, contradicting previous statements in some works (Webster 1970, Ebersohn \& Eicker 1991, Richardson 2007). The number of records, species richness, and estimates of species diversity on each substrate and in each studied area is presented (Table 1). Considering both genera, no clear substrate preference could be detected. Ascobolus and Saccobolus are known generalists on herbivore dung (Van Brummelen 1967, Richardson 2001b, Krug et al. 2004). Cattle dung had the highest number of records. Considering that $S$. glaber was recorded throughout the three areas, the slightly higher number of records on cattle dung is worth noticing. Ascobolus scatigenus, although scarcely recorded during the survey, was found on cattle dung only from two different areas. Coincidently, species richness was equal among substrates. These results indicates that community diversity was similar as well, slightly higher on cattle dung, due to the abundance discrepancies among taxa.

The studied areas represented a gradient between Atlantic rainforest biome and semi-arid Caatinga. Most records were obtained in Serra Talhada Municipality, which had the driest climate and vegetation typical of Brazilian arid environments. The stressful condition of the studied assemblages in this area, subjected to heavy droughts throughout the years of survey, is believed to have suppressed the dominance of competitor species and increased the availability of niches, improving the diversity along the community development (Pugh \& Boddy 1988, Cooke \& Whips 1993, Dix \& Webster 1995). Most species had records somewhat evenly distributed along areas. Ascobolus americanus was typically found in Serra Talhada. Considering the distribution of records on different substrates in the same area, the relationship with the area itself can be deemed superior than the substrate relationship. Recife had the highest species diversity, with three exclusive species, A. crenulatus, S. infestans, and $S$. saccoboloides. 
Table 1 Number of records, species richness and diversity of Ascobolus and Saccobolus assemblages recorded from different dung types and in different areas in Pernambuco, Brazil.

\begin{tabular}{|c|c|c|c|c|c|c|c|c|}
\hline \multirow[b]{2}{*}{ Species } & \multicolumn{3}{|c|}{ Substrate } & \multicolumn{5}{|c|}{ Area } \\
\hline & Cattle & Goat & Horse & Total & Caruaru & Recife & $\begin{array}{c}\text { Serra } \\
\text { Talhada }\end{array}$ & Total \\
\hline Ascobolus americanus & 8 & $\overline{5}$ & 6 & 19 & $\overline{1}$ & $\overline{1}$ & 17 & 19 \\
\hline A. crenulatus & 0 & 1 & 0 & 1 & 0 & 1 & 0 & 1 \\
\hline A. elegans & 0 & 1 & 3 & 4 & 0 & 0 & 4 & 4 \\
\hline A. immersus & 17 & 14 & 17 & 48 & 16 & 12 & 20 & 48 \\
\hline A. scatigenus & 3 & 0 & 0 & 3 & 0 & 2 & 1 & 3 \\
\hline Saccobolus beckii & 2 & 6 & 3 & 11 & 2 & 6 & 3 & 11 \\
\hline S. citrinus & 25 & 15 & 20 & 60 & 21 & 18 & 21 & 60 \\
\hline S. depauperatus & 1 & 3 & 1 & 5 & 2 & 0 & 3 & 5 \\
\hline S. glaber & 10 & 1 & 4 & 15 & 6 & 6 & 3 & 15 \\
\hline S. infestans & 0 & 0 & 1 & 1 & 0 & 1 & 0 & 1 \\
\hline S. minimus & 2 & 1 & 2 & 5 & 2 & 2 & 1 & 5 \\
\hline S. saccoboloides & 1 & 1 & 0 & 2 & 0 & 2 & 0 & 2 \\
\hline S. truncatus & 6 & 0 & 1 & 7 & 1 & 4 & 2 & 7 \\
\hline Number of records $(N)$ & 75 & 48 & 58 & 181 & 51 & 55 & 75 & 181 \\
\hline Species Richness (S) & 10 & 10 & 10 & 13 & 8 & 11 & 10 & 13 \\
\hline Species Diversity $\left(\mathrm{H}^{\prime}\right)$ & 1.84 & 1.79 & 1.77 & 1.91 & 1.51 & 1.95 & 1.79 & 1.91 \\
\hline
\end{tabular}

\section{Acknowledgements}

The authors would like to thank the "Coordenação de Aperfeiçoamento de Pessoal de Nível Superior" (CAPES) and the "Conselho Nacional de Desenvolvimento Científico e Tecnológico" (CNPq-Ciência sem Fronteiras; INCT-Herbário Virtual da Flora e dos Fungos) for providing PhD scolarships to the first author. L.C. Maia acknowledges the research fellowship and grants provided by CNPq (INCT-HVFF, Protax, Sisbiota).

\section{References}

Batista AC, Pontual D. 1948 - Alguns fungos coprófilos de Pernambuco. Boletim da Secretaria de Agricultura Indústria e Comércio do Estado de Pernambuco 15, 27-44.

Bell A. 1983 - Dung Fungi: An Illustrated Guide to Coprophilous Fungi in New Zealand. Victoria University Press, Wellington.

Bell, A. 2005 - An illustrated guide to the coprophilous Ascomycetes of Australia. CBS Biodiversity Series, Utrecht.

Cooke, RC, Whipps, JM. 1993 - Ecophysiology of Fungi. Blackwell Scientific Publications.

da Silva M, Minter DW. 1995 - Fungi from Brazil Recorded by Batista and Co-Workers. Mycological Papers 169, 1-585.

Dix NJ, Webster J. 1995 - Fungal ecology. Chapman \& Hall, London.

Dodge BO, Seaver FJ. 1946 - Species of Ascobolus for genetic study. Mycologia 38, 639-651.

Doveri F. 2004 - Fungi Fimicoli Italici. A.M.B.Fondazione Centro Studi, Livorno.

Doveri F. 2014 - An update on the genera Ascobolus and Saccobolus with keys and descriptions of three coprophilous species, new to Italy. Mycosphere 5(1), 86-135.

Ebersohn C, Eicker A. 1991 - Coprophilous fungal species composition and species diversity on various dung substrates of african game animals. Botanical Bulletin of Academia Sinica. 33, 85-95.

Kirk PM, Cannon PF, Minter DW, Stalpers JA. 2008 - Dictionary of the Fungi. CABI, Wallingford.

Krug JC, Benny GL, Keller, HW. 2004 - Coprophilous fungi. 467-499, in Mueller GM et al. (eds.), Biodiversity of fungi. Inventory and monitoring methods. Elsevier Academic Press, London. 
Melo RFR, Bezerra JL,Cavalcanti MAQ. 2012 - Diversity of coprophilous Ascomycetes from captive wild animals in Dois Irmãos State Park, Brazil. Nova Hedwigia 94, 153-162.

Pugh, GJF, Boddy L. 1988 - A view of disturbance and life strategies in fungi. Proceedings of the Royal Society of Edinburgh 94B, 3-11.

Richardson MJ. 2001a - Coprophilous Fungi from Brazil. Brazilian Archives of Biology and Technology 44, 283-289.

Richardson, M.J. 2001b - Diversity and occurrence of coprophilous fungi. Mycological Research $105,387-402$.

Richardson MJ. 2007 - The distribution and ocurrence of Ascobolaceae. Mycologia Montenegrina $10,211-227$.

Richardson MJ, Watling R. 1997 - Keys to Fungi on Dung. British Mycological Society, Stourbridge.

Shannon CE. 1948 - A mathematical theory of communication. The Bell System Technical Journal, 27, 379-423 and 623-656.

Spegazzini, C. 1899 - Fungi Argentini novi vel critici. Anales del Museo Nacional de Historia Natural Buenos Aires 6: 81-365.

Webster J. 1970 - Presidential Address. Coprophilous fungi. Transactions of the Britsh Mycological Society 54, 161-180.

Van Brummelen J. 1967 - A world monograph of the genera Ascobolus and Saccobolus. Persoonia, Supplement 1, 1-260.

www.iapt-taxon.org - 2011 .

www.indexfungorum.org -2011 . 